\section{Towards more effective FDA premarket review of new tobacco products}

\author{
Matthew L Myers
}

Until the enactment of the Family Smoking Prevention and Tobacco Control Act of 2009 (Tobacco Control Act or TCA), the tobacco industry was not required to inform the public or any governmental agency when it introduced new products, changed old products or made changes to the design of products, even when the new or modified products were more deadly, more addictive or appealed to children. The tobacco industry was free to introduce new products and make changes in secret without regard to the public health impact of its actions. The implications for public health have been devastating. Today's cigarettes carry an even greater risk of causing lung cancer than cigarettes from decades ago; ${ }^{i}$ they deliver nicotine in far more sophisticated ways; and until the 2009 Act came in flavours that were highly appealing to children.

The 2009 Tobacco Control Act for the first time required the tobacco companies to notify the government before it introduced new products or changed existing products, explain the nature of the changes and provide the government with information about the impact of those changes on the toxicity, addictiveness and appeal of the product before moving forward. The statute also placed the burden on the tobacco industry to prove to the Food and Drug Administration (FDA) that the introduction of a new product is 'appropriate for the protection of the public health' and that the introduction of changed products does not raise 'different questions of public health'.

Although the statute was enacted on 20 June 2009, it applied the new public health and premarket review requirement retroactively to any products introduced or changes made subsequent to 15 February 2007. However, it allowed

indeed, the Surgeon General's 50th Anniversary Report in 2014 made the startling finding that changes in the design and composition of cigarettes had made them even more lethal than those sold 50 years before. ${ }^{1}$

Correspondence to Matthew L Myers, Campaign for Tobacco-Free Kids, Washington DC 20005, USA; mmyers@tobaccofreekids.org products introduced between 15 February 2007 and 21 months after the date of enactment to remain on the market until FDA had completed its review of any applications submitted by the companies for those products.

It is hard to overstate the importance of these requirements. For the first time, it gave the government the ability to know what the industry was doing to its products, to control the introduction of new and changed products, and it made public health the primary criteria for entry into the marketplace. At the same time, it is hard to overstate the magnitude of the challenge that FDA faced. It not only had to build a new staff with the scientific capability of carrying out these new responsibilities, it had to do so with little scientific precedent and the need to articulate the criteria that would be applied to the broad 'public health' standard and do so while facing intense scrutiny from the public and the tobacco industry.

How has FDA carried out this new authority? Jenson and collegues, writing in this issue of Tobacco Control, raise important questions about the impact of how FDA is implementing its new authority. There is no question about FDA's commitment to public health, but it is entirely appropriate to raise questions about the impact of FDA's decisions. This is not the first time questions have been raised about the impact of how FDA has carried out its new authority. In a series of letters to FDA, including a 26 February 2016 letter joined by 36 public health and medical organisations, others have pointed to the introduction of products into the marketplace that the industry has promoted as 'new' by their manufacturers, without any apparent FDA authorisation or review by FDA - in apparent disregard of the statute.

Based on the information publicly available, there is serious reason for concern. While the FDA has prioritised processing applications for products the industry is not allowed to market prior to FDA review, under pressure from the tobacco companies, the thousands of products the tobacco industry rushed to the market prior to March 2011 have received far too little focus, with the net result that they continue on the market without regard to their threat to public health.
Similarly, there are too many examples of products that the tobacco industry has proclaimed as 'new' without any evidence that they have undergone review by the FDA or any evidence that FDA has ordered that they be pulled from the market pending review. Lastly, the public record has raised important questions about whether the FDA has acted boldly to dismiss applications promptly when the applications filed by the manufacturer fail to meet their burden to prove that new or modified products do not attract new tobacco users, do not impact the addictiveness of the products and do not impact the health risk to smokers, other than to reduce that risk.

As Jensen and colleagues indicate, the public record demonstrates that the FDA has prioritised the review of products not yet on the market. Yet, over 3500 provisional substantial equivalence applications were submitted before the 22 March 2011 deadline for products already on the market. It was not until September of 2015, that FDA first ordered a major cigarette brand to be pulled off the market as not substantially equivalent. Camel Crush Bold featured a crushable menthol capsule in the filter, allowing the user to choose whether to convert from a regular to a menthol cigarette. The crushable capsule is the kind of innovation likely to stimulate initiation of smoking, particularly in young people, as well as making the brand more appealing to current smokers.

The FDA order requiring the removal of Camel Crush Bold from the market stands as an important precedent illustrating the potential of the premarket review process to protect the public. If FDA had set different priorities would Camel Crush have remained on the market for over 4 years?

Another example given by Jenson and colleagues is Marlboro Midnight, a menthol brand that an industry analyst has said is targeted to 'a younger demographic', which Philip Morris USA announced in October of last year as a 'new and exciting' product and the company's 'latest innovation'. ii According to the Marlboro website, the brand is now 'available coast to coast'. ${ }^{\text {iii }}$ Yet, there is no premarket order permitting the introduction of this brand on FDA's website.

Similarly, in a 15 December 2015 press release, 22nd Century Group, Inc

ii Presentation of Marty Barrington, CEO of Altria Group, Briefing of Investor Analysts on Third Quarter Earnings, 29 October 2015.

iii http://marlboro.com. 
announced the introduction of Red Sun cigarettes as 'extremely nicotine'. ${ }^{\text {iv }}$ The company president said "no other brand matches Red Sun's extreme nicotine" (emphasis in original).

In its press release, the company refers to Red Sun as 'very new to the market' and indicates that the company launched the brand 'less than 1 year ago'.' Unless these references are themselves inaccurate, the product is a 'new product' under the law but once again no premarket review order has been posted. Even if Red Sun had been introduced into commerce prior to 23 March 2011, ${ }^{\text {vi }}$ its high-nicotine

\footnotetext{
iv “22nd Century's RED SUN Brand Launches Extremely Nicotine Campaign," Press Release, 21 December 2015.

${ }^{\mathrm{v}} \mathrm{Id}$.

${ }^{\mathrm{vi}}$ This is possible, given that on 19 April 2011, Goodrich Tobacco Company, a subsidiary of 22nd Century Group, issued a press release stating that it had 'introduced RED SUN brand cigarettes to the tobacco trade' at the National Association of Tobacco Outlets trade show in Las Vegas. Later statements by 22nd Century Group indicated that it had introduced the brand in 'early 2011', but that 'sales have been intentionally curtailed by the Company in order to limit the complexity and costs
}

product should have led to its quick removal from the marketplace.

Jenson and colleagues make a number of constructive suggestions for improvement over the long run, including the need for greater transparency of the process itself. Right now, for example, the public does not know what products are the subject of provisional substantial equivalence applications, even though these are products that are already on the market and therefore cannot be regarded as 'trade secrets'.

The power given to FDA to regulate the introduction of new tobacco products and to prevent changes in existing tobacco products has the potential to have a fundamental impact of the effort to reduce the number of people who suffer from tobacco-caused disease, but it will only be realised if FDA carries out its unprecedented authority with a sharp focus on the nation's public health.

associated with becoming a signatory of the MSA'. "22nd Century Group Becomes a Member of Tobacco Master Settlement Agreement," Press Release, 2 September 2014. Thus, the history of the company's public statements create uncertainty as to when Red Sun was introduced to the market.
Competing interests None declared.

Provenance and peer review Commissioned; internally peer reviewed.

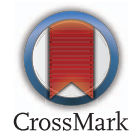

To cite Myers ML. Tob Control 2016;25:243-244.

Accepted 18 March 2016

Published Online First 11 April 2016

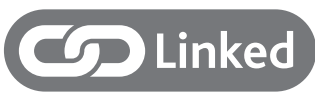

- http://dx.doi.org/10.1136/tobaccocontrol-2015052391

Tob Control 2016;25:243-244.

doi:10.1136/tobaccocontrol-2016-053055

\section{REFERENCES}

1 US Department of Health and Human Services. The health consequences of smoking: 50 years of progress. A report of the Surgeon General. Atlanta, GA: US Department of Health and Human Services, Centers for Disease Control and Prevention, National Center for Chronic Disease Prevention and Health Promotion, Office on Smoking and Health, 2014.

2 Kress M. The Resurgence of Combustible Cigarettes Continues. Convenience Store News 26 October 2015. 